\title{
Correction to: Thermally Efficient Coplanar Architecture of Microheater and Inter-digitated Electrodes for Nanolayered Metal Oxide Based Hydrogen Gas Sensor
}

\author{
Sumit Maan ${ }^{1} \cdot$ Ankur Garg $^{1}$ (D) Manish Deshwal ${ }^{1}$ (I)
}

Published online: 13 January 2021

(c) The Korean Institute of Electrical and Electronic Material Engineers 2021

\section{Correction to: \\ Transactions on Electrical and Electronic Materials \\ (2019) 20:542-547 \\ https://doi.org/10.1007/s42341-019-00147-1}

In the original publication of the article, the first author name was published incorrectly. The correct author name is given in this correction.

Publisher's Note Springer Nature remains neutral with regard to jurisdictional claims in published maps and institutional affiliations.

The original article can be found online at https://doi.org/10.1007/ s42341-019-00147-1.

Manish Deshwal

Deshwal.manish@gmail.com

Sumit Maan

sumitmaan28october@gmail.com

Ankur Garg

ankurgarg151@gmail.com

1 Electronics and Communication Engineering Department,

Chandigarh University, Mohali, Punjab, India 